\title{
ВПЛИВ МЕДСЕСТРИНСЬКОГО ДОГЛЯДУ НА ЯКІСТЬ ЖИТТЯ ПАЛІАТИВНИХ ПАЦІЕНТІВ
}

\author{
Т. В. Томчук, А. О. Боб, Г. О. Лукіна \\ Луцький базовий медичний коледж \\ ДВНЗ «Тернопільський державний медичний університет \\ імені І. Я. Горбачевського МОЗ Украӥни» \\ ННI медсестринства \\ КЗ «Криворізьке училище підвищення кваліфікації та перепідготовки молодих \\ медичних і фармацевтичних спеціалістів Дніпропетровської обласної ради"
}

\begin{abstract}
Якість життя - один із феноменів, що відображає особливості переживання людиною актуальної життєвої ситуації у зв’язку з порушенням здоров'я. Забезпечення, підтримка і покращення якості життя тяжкохворих - основна мета паліативної медицини. Медична сестра, співпрацюючи 3 членами мультидисциплінарної команди, здійснюючи кваліфікований професійний догляд та підтримку паліативних пацієнтів, допомагає покращити їхню якість життя.
\end{abstract}

\section{NURSING INFLUENCE ON THE PALLIATIVE PATIENTS LIFE QUALITY}

\author{
T. V. Tomchuk, A. O. Bob, H. O. Lukina \\ Lutsk Base Medical College \\ I. Horbachevsky Ternopil State Medical University \\ Educational-Scientific Institute of Nursing \\ Kryvyi Rih Training School of Junior Medical Specialists and Pharmacists
}

\begin{abstract}
The life quality is one of the phenomena, which reflects the person's experiencing of the current life situation connected with health problems. Providing, keeping and improving of the seriously ill patients' life quality is the main aim of the palliative medicine. The nurse in cooperation with multidisciplinary team, giving high professional care and support to the palliative patients, helps to improve their life quality.
\end{abstract}

Вступ. Якість життя (ЯЖ) - це інтегральна характеристика фізичного, психологічного, емоційного і соціального функціонування здорової чи хворої людини, заснована на її суб'єктивному сприйнятті [1].

Дослідження яЖ дозволяє вивчити вплив захворювання і лікування на показники ЯЖ хворої людини, оцінюючи всі складові здоров'я - фізичне, психологічне та соціальне функціонування [2]. Найбільш повно та точно розкриває суть якості життя визначення, сформульоване Всесвітньою організацією охорони здоров'я: «якість життя - це сприйняття людиною своєї позиції у житті, у тому числі фізичного, психічного та соціального благополуччя, залежно від якості середовища, в якому вона живе, а також рівня задоволення життям та іншими складовими психологічного комфорту» [3]. Тут важливо відзначити складові здоров'я, які впливають на його якість, а саме: екологія (20 \%), спадковість (20\%), спосіб життя людини (50 \%), меди-

() Т. В. Томчук, А. О. Боб, Г. О. Лукіна 2017 цина (10\%), а також мотивація на здоров'я, розуміння здоров'я, оптимізм.

Паліативна допомога (ПД) - це комплексний підхід, мета якого - забезпечити максимальну якість життя пацієнта з невиліковним (смертельним) захворюванням і членів його родини шляхом запобігання та полегшення страждань, завдяки ранньому виявленню і точному діагностуванню (оцінці) проблем, що виникають, та проведенню адекватних лікувальних заходів (при больовому синдромі та інших розладах життєдіяльності), а також полегшення психологічних та духовних проблем [4]. Головною метою ПД $є$ підтримка яж у фінальній стадії, максимальне полегшення фізичних та моральних страждань пацієнта та його близьких, а також збереження людської гідності пацієнта [5]. Паліативний пацієнт - це пацієнт усіх вікових груп, хвороба якого не піддається лікуванню, спрямованому на одужання [6]. Кінцевий період життя для паліативного пацієнта та членів його сім'і $є$ етапом

36 ISSN 2411-1597. МЕДСЕСТРИНСТВО. 2017. № 1 
випробувань: фізичних, психологічних, духовних, соціальних. У цій ситуації важливе місце займають фізичні страждання, зокрема сильний біль, порушення функцій та, як наслідок, втрата можливості до самообслуговування. Для задоволення фізіологічних потреб пацієнта, зменшення фізичних страждань потрібен кваліфікований медсестринський догляд та опіка. Роль медичної сестри полягає у контролі фізичного стану хворого, консультуванні та навчанні пацієнта та його рідних і близьких навичкам догляду. Це дасть можливість покращити ЯЖ паліативного пацієнта.

Для дослідження яж було використано один із найбільш поширених загальних опитувальників EuroQol-5D-5L (European Quality of Life Questionnaire) [7]. Дослідження проводилося у 2016 р. на базі Волинської обласної лікарні «Хоспіс». Метою дослідження було провести аналіз впливу кваліфікованого медсестринського догляду на якість життя паліативних пацієнтів у Волинській обласній лікарні «Хоспіс».

Відбір пацієнтів здійснювався за рівнем функціональних можливостей до спілкування. Всього у дослідженні брали участь 36 пацієнтів: 18 пацієнтів у перший тиждень після госпіталізації у хоспіс (група 1) та 18 пацієнтів, які перебувають у хоспісі більше 6 місяців (група 2).

Основна частина. Опитувальник EuroQol-5D5L складається з двох частин: перша частина EQ-5Q profile - це профіль, що містить 5 компонентів, пов'язаних із такими сферами життя, як: рухомість, самообслуговування, щоденна активність, біль (дискомфорт), тривога (депресія). Другою частиною $\epsilon$ EQ VAS (EQ Visual Analogue Scale) - візуальна аналогова шкала для реєстрації індивідуального рейтингу свого поточного стану, пов'язаного із здоров'ям [8].

Якість життя - це здатність індивідуума функціонувати в суспільстві відповідно до свого положення і отримувати задоволення від цього. В більшості випадків дослідників цікавлять не загальний показник Яж як такий, а його компоненти: задоволеність людини ступенем фізичного (активність, рухомість, можливість самообслуговування), психологічного (емоційний фон,у тому числі відчуття щастя або страждання), соціального (можливість участі в суспільній діяльності, контакти, обмеження можливостей за станом здоров'я вплані навчання, роботи, відпочинку), духовного благополуччя; загальне сприйняття стану свого здоров'я і благополуччя [9].

У медичній практиці на сучасному етапі якості життя приділяється велика увага. При цьому пацієнт розглядається не тільки як суб'єкт лікування, але й як особистість, яка під впливом хвороби змінюється і по- вертається до соціуму в іншому статусі - статусі хворої людини. Всебічне вивчення складових яЖ дозволяє визначити рівень якості життя як окремої особи, так і цілих груп, і встановити, за рахунок якого складника він підвищується чи знижується та на що необхідно вплинути, щоб покращити якість життя (скоригувати лікування, надати соціальну підтримку та ін.) [3].

Результати опитування пацієнтів Волинської обласної лікарні «Хоспіс» показали, що всі пацієнти вказали на проблеми, які стосуються всіх компонентів якості життя. Виключно всі пацієнти мають проблеми з руховою активністю: 50 \% групи 1 не можуть виходити на прогулянку, в групі 2 таких пацієнтів 61 \%. Значні труднощі під час прогулянки мають пацієнти обох груп 28 \% та 11 \% відповідно. Помірні труднощі під час руху виявляють 22 \% госпіталізованих пацієнтів хоспісу та $17 \%$ тих, хто перебуває там останніх пів року. Незначні труднощі мають $11 \%$ хворих групи 1 та 17 \% пацієнтів групи 2. Немає пацієнтів, які не відчувають труднощів під час прогулянки. Дані результати свідчать про те, що обидві досліджувані групи пацієнтів потребують допомоги медичної сестри для задоволення потреб у русі.

У всіх пацієнтів спостерігається дефіцит самодогляду та самообслуговування. Більшою мірою у пацієнтів групи 1, вони мають помірні (6 \%) та значні (28 \%) труднощі у здійсненні догляду за собою, 67 \% пацієнтів взагалі не можуть самостійно одягнутися і здійснити гігієнічні заходи.

У групі 2 медичні сестри здійснюють навчання пацієнтів щодо самодогляду, проте беручи до уваги їхній фізичний стан, багато пацієнтів все ж таки не можуть здійснити це самостійно. У групі $239 \%$ пацієнтів не можуть самостійно помитися, вдягнутися та $39 \%$ відчувають при цьому значні труднощі. Помірні труднощі виникають в 11 \% опитаних пацієнтів, також 11 \% мають незначні труднощі у здійсненні догляду за собою. Відповідно таким пацієнтам складно виконувати повсякденну діяльність. В пацієнтів обох груп виникають помірні або значні труднощі під час роботи, ходьби та виконання повсякденних справ: 28 \% у групі 1 та 33 \% у групі 2 взагалі не можуть займатися повсякденною діяльністю. Пацієнти, які перебувають на стаціонарному лікуванні у хоспісі менше відчувають біль та дискомфорт. Це звичайно пов'язано зі здійсненням кваліфікованого медсестринського догляду. У групі 233 \% пацієнтів спостерігають легкий біль, $44 \%$ - помірний, $17 \%$ сильний біль. Біль є суб'єктивним відчуттям та психоемоційним переживанням, що виникає як реакція організму на дію шкідливих, руйнівних подразнень. Тяжке відчуття 
болю, що виникає у пацієнта, формує стійкі патологічні реакції у периферичній та центральній нервовій системі. Такий патологічний біль $\epsilon$ небезпечним для організму і може спричинити розвиток патопсихологічних змін. У групі 122 \% відчувають помірний, 55 \% сильний та 22\% опитаних дуже сильний біль.

Такий біль здатний знищити людину, як особистість, призвести до розвитку стану депресії. На стан помірної депресії вказали 11 \% пацієнтів групи 1, сильний неспокій та депресію відмітили 78 \% пацієнтів, дуже сильну депресію вказали 11 \% відповідно. На стан легкого занепокоєння та відсутності депресії не вказав ніхто. У групі 2 пацієнти протягом останніх півроку отримують кваліфікований медсестринський догляд та опіку, відповідно, і рівень відчуття занепокоєння та депресії є значно меншим. Не виявлено пацієнтів із дуже сильними відчуттями туги та смутку. Сильне занепокоєння та депресію мають 11 \% пацієнтів, 61 \% - спостерігають помірний рівень цього відчуття та 21 \% опитаних вказали на легкий ступінь. Немає пацієнтів у групі 2 опитаних, які взагалі не відчувають туги та смутку, це можна пояснити тяжким діагнозом та пов'язаними з цим переживаннями. Результати опитування наведено в таблиці.

таблиця. Результати опитування пацієнтів Волинської обласної лікарні «Хоспіс» за EQ-5Q profile

\begin{tabular}{|c|c|c|c|c|}
\hline \multirow{3}{*}{ Компоненти опитувальника } & \multicolumn{4}{|c|}{ Кількість опитаних (n=36) } \\
\hline & \multicolumn{2}{|c|}{ Група 1 (n=18) } & \multicolumn{2}{|c|}{ Група 2 (n=18) } \\
\hline & a6c. & $\%$ & абс. & $\%$ \\
\hline \multicolumn{5}{|l|}{ Активність-рухомість } \\
\hline Я не відчуваю труднощів під час прогулянки & 0 & 0 & 0 & 0 \\
\hline Я відчуваю незначні труднощі під час прогулянки & 2 & 11 & 3 & 17 \\
\hline Я відчуваю помірні труднощі під час прогулянки & 4 & 22 & 3 & 17 \\
\hline Я відчуваю значні труднощі під час прогулянки & 5 & 28 & 2 & 11 \\
\hline Я не в змозі прогулюватись & 9 & 50 & 11 & 61 \\
\hline \multicolumn{5}{|l|}{ Догляд за собою } \\
\hline Я не відчуваю труднощів з тим, щоб помитися та вдягнутися & 0 & 0 & 0 & 0 \\
\hline Я відчуваю незначні труднощі з тим, щоб помитися та вдягнутися & 0 & 0 & 2 & 11 \\
\hline Я відчуваю помірні труднощі з тим, щоб помитися та вдягнутися & 1 & 6 & 2 & 11 \\
\hline Я відчуваю значні труднощі з тим, щоб помитися та вдягнутися & 5 & 28 & 7 & 39 \\
\hline Я не в змозі самостійно помитися та вдягнутися & 12 & 67 & 7 & 39 \\
\hline \multicolumn{5}{|c|}{ Повсякденна діяльність (робота, хобі, родина) } \\
\hline Я не відчуваю проблем у повсякденній діяльності & 0 & 0 & 0 & 0 \\
\hline Я відчуваю невеликі проблеми в повсякденній діяльності & 1 & 6 & 1 & 6 \\
\hline Я відчуваю помірні проблеми в повсякденній діяльності & 8 & 44 & 4 & 22 \\
\hline Я відчуваю великі проблеми в повсякденній діяльності & 4 & 22 & 7 & 39 \\
\hline Я не в змозі займатися повсякденною діяльністю & 5 & 28 & 6 & 33 \\
\hline \multicolumn{5}{|l|}{ Біль, дискомфорт } \\
\hline Я не відчуваю біль та дискомфорт & 0 & 0 & 1 & 6 \\
\hline Я відчуваю легкий біль та дискомфорт & 0 & 0 & 6 & 33 \\
\hline Я відчуваю помірний біль та дискомфорт & 4 & 22 & 8 & 44 \\
\hline Я відчуваю сильний біль та дискомфорт & 10 & 55 & 3 & 17 \\
\hline Я відчуваю дуже сильний біль та дискомфорт & 4 & 22 & 0 & 0 \\
\hline \multicolumn{5}{|c|}{ Занепокоєння, депресія (туга, смуток) } \\
\hline Я не відчуваю занепокоєння та депресію & 0 & 0 & 0 & 0 \\
\hline Я відчуваю легке занепокоєння та депресію & 0 & 0 & 5 & 28 \\
\hline Я відчуваю помірне занепокоєння та депресію & 2 & 11 & 11 & 61 \\
\hline Я відчуваю сильне занепокоєння та депресію & 14 & 78 & 2 & 11 \\
\hline Я відчуваю дуже сильне занепокоєння та депресію & 2 & 11 & 0 & 0 \\
\hline
\end{tabular}


Друга частина опитувальника - EQ VAS (EQ Visual Analogue Scale) візуальна аналогова шкала - це метод, побудований на використанні стандартизованої розширеної версії аналогової вертикальної шкали візуального рейтингу VAS з кінцевими точками, що відповідають найкращому стану здоров'я у верхній і гіршому стану здоров'я у нижчій точці з числовими значеннями 0 і 100 відповідно. Це так званий «термометр здоров'я» [8]. Пацієнт робить позначку на шкалі від 0 до 100 у точці, що відповідає стану його здоров'я в даний момент. Дані візуальної аналогової шкали наведено на рисунку.

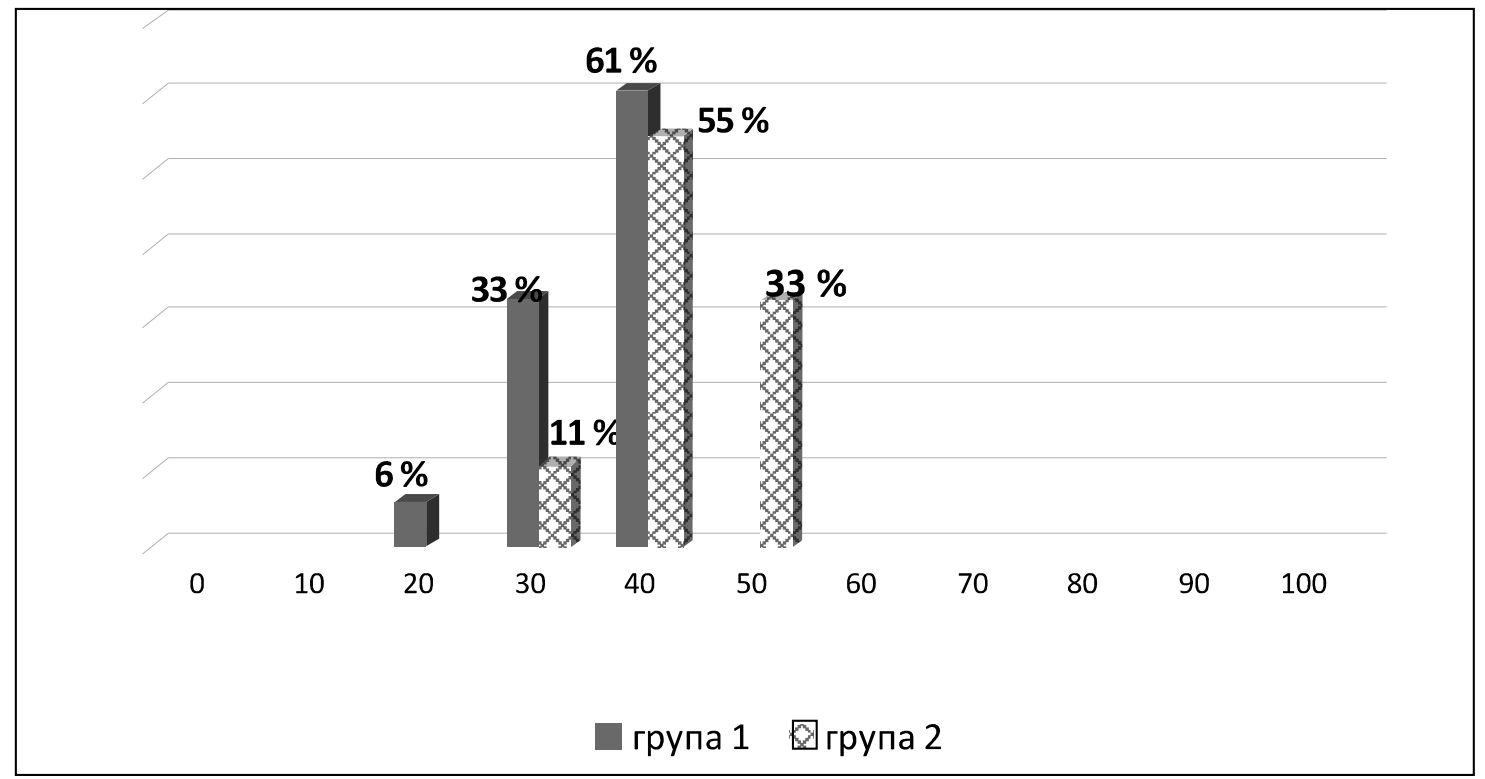

Puc. Результати опитування пацієнтів Волинської обласної лікарні «Хоспіс» за EQ VAS.

У більшості хворих була знижена оцінка загального стану здоров'я. Середній показник якості життя за «термометром» EuroQol-5D у пацієнтів Волинської обласної лікарні «Хоспіс» у групі 1 становить 25,6, у групі 2 - 42,2. Це можна пояснити тим, що більшість пацієнтів не може здійснювати повноцінне життя, не має шансу на одужання, їхній діагноз і подальше симптоматичне лікування не приносить видужання, але все ж таки професійний догляд зменшує страждання та покращує самопочуття хворого навіть у такій ситуації.

Взаємозалежність якості медсестринського догляду та ЯЖ досить складна. Логічно припустити, що чим кращий догляд, більша опіка, тим вищою $є$ якість життя. Така закономірність спостерігається у більшості випадків, але не завжди. Так, у пацієнтів хоспісу зменшення інтенсивності болю не обов'язково супроводжується покращенням якості життя. Ймовірно, це пов'язано з тим фактом, що усвідомлення свого стану та прогресування хвороби загалом не може змінити прогноз. При оцінці впливу догляду на яЖ необхідно враховувати особливості розвитку термінального періоду захворювання, який призводить до появи нових симптомів, тим самим погіршуючи якість життя.
Крім того, часто сам факт необхідності паліативного лікування та перебування в хоспісі може негативно сприйматися пацієнтом і, відповідно, наслідком $є$ психологічні проблеми.

Тяжка хвороба може істотно впливати на фізичний стан, поведінку людини, емоційні реакції, а також змінити її місце і роль в суспільному житті. При наданні паліативної допомоги потрібно врахувати важливу роль кваліфікованого медсестринського догляду, безпосередню участь пацієнта у ньому та активне його залучення до співпраці. Тільки пацієнт може надати адекватну інформацію про ступінь задоволення своїх потреб, пов'язаних із симптомами захворювання та його наслідками. Тільки медична сестра може врахувати усі ці потреби, визначити проблеми, інтерпретувати їх, спланувати, відповідно, догляд та належним чином його здійснити.

Якість життя по-різному сприймається та оцінюється, зокрема, коли у людини порушується задоволення фізіологічних потреб, з'являється дефіцит самодогляду та самообслуговування. У такому випадку роль медичної сестри є важливою та незамінною. У випадку, коли людина потрапляє у хоспіс, вона переосмислює 
своє життя, а хвороба у цьому стані змінює погляди на життя. Негатив, який $є$ наслідком захворювання (депресія, паніка, страх тощо), змінює характер соціальних відносин, способу життя та вимагає відповідного пристосування до навколишнього середовища та задоволення потреб насамперед фізіологічних.

Висновки. Оцінка якості життя у паліативній медицині є важливим критерієм ефективності роботи медичної сестри при наданні паліативної допомоги. Метою паліативної допомоги $є$ не скорочення чи продовження життя, а саме покращення його якості. Догляд за пацієнтом не впливає на прогноз, але може істотно покращити Яж, зменшуючи прояви захворювання, частоту ускладнень. У Волинській об-

\section{СПИСОК ЛІТЕРАТУРИ}

1. Programme on mental health/WHOQOL. Measuring quality of health. Mental Health publications [Electronic resource]. - Assess mode : http://www.who.int/mental_ health/media/

2. Брацюнь О. П. Вплив міждисциплінарного підходу в наданні паліативної допомоги на якість життя паліативних пацієнтів (на прикладі роботи першого денного хоспісу в Україні) / О. П. Брацюнь, Г. М. Науменко // Реабілітація та паліативна медицина. - 2016. - № 1. - С. 80-83.

3. Ягенський А. В. Оцінка якості життя у сучасній медичній практиці / А. В. Ягенський, І.М.Січкарук // Внутренняя медицина. - 2007. - № 3 (3). - С. 21-23.

4. Визначення паліативної допомоги Всесвітньої організації охорони здоров'я [Електронний ресурс]. - Режим доступу: http://www.who.int/cancer/palliative/definition/en/

5. Рега Н. І. Оцінка якості роботи медичних сестер 3 інкурабельними хворими в гематологічному відділен- ласній лікарні «Хоспіс» ми виявили кращі показники якості життя у пацієнтів, які отримують кваліфікований медсестринський догляд. Пацієнти хоспісу, порівняно з тими, кого доглядали вдома, не відчувають дуже сильного болю та не мають дуже сильного занепокоєння та депресії. Хоча проблеми з активністю та самодоглядом $€$ однаковою мірою у всіх пацієнтів. За «термометром здоров'я» середній показник якості життя в групі 1 становить 25,6, у групі 2 - 42,2. Враховуючи те, що діагноз та симптоматичне лікування не забезпечать одужання, та все ж професійний медсестринський догляд зменшує страждання, покращує самопочуття хворого та, як наслідок, підвищує яж паліативних пацієнтів.

ні К3 ТОР «Тернопільська університетська лікарня» / Н. І. Рега, Б. А. Локай, С. О. Ястремська // Медсестринство. 2015. - № 1. - С. 4-8.

6. Про організацію паліативної допомоги в Україні : наказ МОЗ України від 21.01.2013 р. № 41 [Електронний ресурс]. - Режим доступу : http://www.zakon.rada.gov.ua/ go/z0229-13.

7. Spiraki C. Health-related quality of life measurement in patients admitted with coronary heart disease and heart failure to a cardiology department of a secondary urban hospital in Greece / C. Spiraki, D. Kaitelidou // Hellenic J. Cardiol. - 2008.- Vol. 49.- P. 241-247.

8. A single European currency for EQ-5D health states. Results from a six country study. // W Greiner, T Weijnen, M Nieuwenhuizen, [et al.] Eur. J. // Health Econ. - 2003. Vol. 4(3). - P. 222-231. 